\title{
The Effect of Work Loads and Work Stress on Motivation of Work Productivity (Empirical Case Study of Ink-Producing Companies)
}

\author{
Astria Semaksiani $^{1 *}$, Agung Wahyu Handaru ${ }^{2}$, Mohamad Rizan ${ }^{2}$
}

${ }^{1}$ Student of State University of Jakarta

${ }^{2}$ Lecture of State University of Jakarta

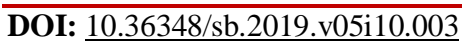

| Received: 15.10.2019 | Accepted: 22.10.2019 | Published: 30.10.2019

*Corresponding author: Astria Semaksiani

\section{Abstract}

This study aims to analyze: 1) the effect of workload on motivation on employees of PT Sumber Harapan Abadi. 2) the influence of Job Stress influences motivation on the employees of PT Sumber Harapan Abadi. 3) the effect of workload has an effect on productivity on the employees of PT Sumber Harapan Abadi. 4) the effect of work stress has an effect on productivity on the employees of PT Sumber Harapan Abadi. 5) the influence of motivation has an effect on productivity on the employees of PT Sumber Harapan Abadi. The research method is: quantitative research using a survey method in question is to explain the causal relationship or correlation commonly called path analysis(path analysis). The respondents were 147 employees of PT Sumber Harapan Abadi employees. The results of the study are: 1) the influence of workload on motivation on the employees of PT Sumber Harapan Abadi. 2) the influence of work stress on motivation on the employees of PT Sumber Harapan Abadi. 3) the influence of workload on productivity on the employees of PT Sumber Harapan Abadi 4) the influence of work stress on productivity on the employees of PT Sumber Harapan Abadi. 5) the influence of motivation on productivity on the employees of PT Sumber Harapan Abadi.

Keyword: Productivity, workload, work stress and work motivation.

Copyright @ 2019: This is an open-access article distributed under the terms of the Creative Commons Attribution license which permits unrestricted use, distribution, and reproduction in any medium for non-commercial use (NonCommercial, or CC-BY-NC) provided the original author and source are credited.

\section{INTRODUCTION}

This research was conducted at PT. Sumber Harapan Abadi as a supplier of Dataprint ink content, which is located at Jalan Garuda Number 12, RT 01
RW 01, Kemayoran, Jakarta. Based on preliminary data obtained, it is known that the level of production capacity continues to decline every year. The following production data per year PT. Sumber Harapan Abadi:

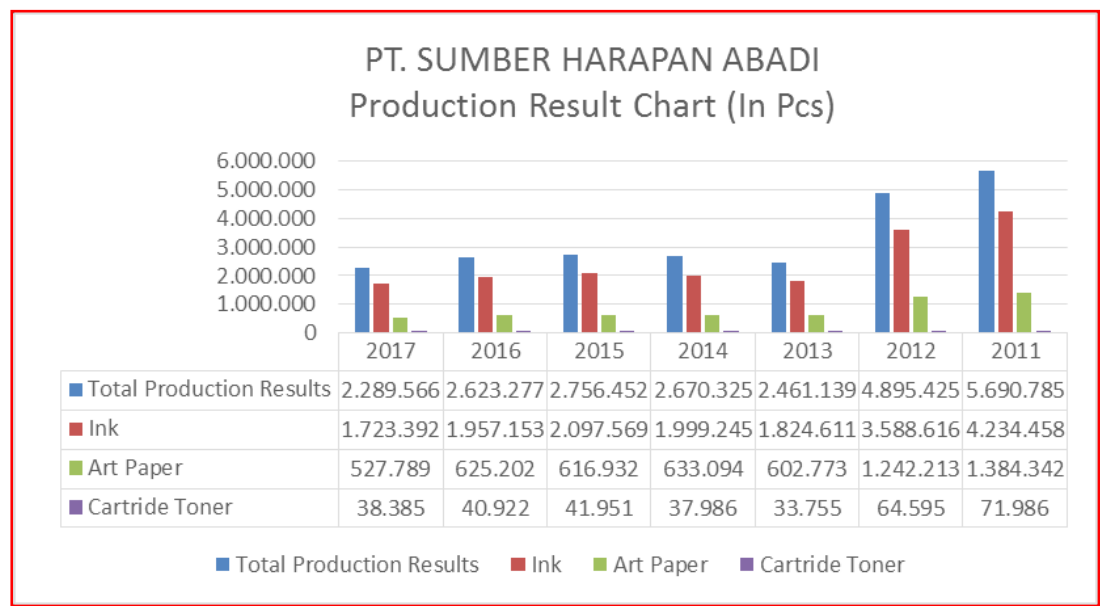

Fig-1: Production Results of PT. Sumber Harapan Abadi (2011-2017)

Source: Production Division of PT. Sumber Harapan Abadi, 2018 The 
Data above is a graph of PT. Sumber Harapan Abadi Based on the table, it appears that production results have decreased quite significantly each year, from total production in 2011 which reached 5 million decreased to 2 million in 2017. This is allegedly because employees are exhausted so that they are not maximized in carrying out tasks and achieving their targets. To maintain work productivity requires hard work from all elements in the company so that company productivity can be maintained. In addition to increasingly fierce business competition, of course the workload of employees must be considered by companies.

The workload of PT. Sumber Harapan Abadi's production division is targeted to be able to produce 25,000 ink bottles / day and 15 pcs / day art paper with working hours Monday through Saturday. The workload does not include overtime work (Interview with Munawar, Senior Sales Manager of PT. Sumber Harapan Abadi). If seen from the total production of ink and paper produced, the workload generated by employees has not been reached. The achievement of productivity is certainly not also influenced by other variables that are thought to influence work motivation. In an effort to achieve the targets set by the company, employees are required to have high work productivity. However, many employees unwittingly experience work stress due to workload fatigue.

Job stress arises when employees are unable to meet the demands of the job, as well as unclear what is the responsibility of the job. Stress is a condition of tension that creates physical and psychological imbalances that affect emotions, thought processes and conditions of an employee.

Another variable is work motivation. Increased employee motivation basically depends on the attitude of the employees themselves in doing a job. So, work motivation itself is very important for employees. Without work motivation, every employee cannot carry out his work productively and efficiently. Therefore, the company's management must carry out various activities related to employees in order to increase employee motivation.

Based on the empirical background and literature described above, I am interested in conducting research under the title "Effect of workload and work stress on employee motivation and work productivity: the case of ink-producing companies".

\section{LITERATURE REVIEW Workload}

Workload is a key aspect that forms the basis for calculating employee formation. Workloads need to be determined through work unit programs which are then translated into job targets for each position (Kepmenpan No: KEP / 75 / M.PAN / 7/2004) [1]

According to Menpan [1], workload is a number of work targets or target results that must be achieved within a certain time unit. Workload measurement is defined as a technique for obtaining information about the efficiency and effectiveness of the work of an organizational unit, or position holders carried out systematically using job analysis techniques, workload analysis techniques or other management techniques. Furthermore, it was also stated, that the measurement of workload is one of the management techniques to obtain position information, through a research and assessment process conducted in an analytical manner. The position information is intended as a tool to perfect the apparatus, both in the fields of institutional, management and HR.

According to Prihatini [2], every work is a burden for the culprit. The burden depends on how the person works so called workload. So, workload can be defined as the ability of the human body to accept work. Meanwhile, Permendagri No. 12/2008 states that workload is the amount of work that must be borne by an office / organizational unit and is the product of work volume and time norms. If the ability of workers is higher than the demands of the job, boredom will emerge. However, on the contrary, if the ability of workers is lower than the demands of the job, more fatigue will emerge.

Workloads charged to employees can be categorized into three conditions, namely workloads that are in accordance with standards, workloads that are too high (over capacity) and workloads that are too low (under capacity). The demands of a job or a combination of jobs include maintaining stability in attitude, performing physical actions, and performing cognitive work (performing cognitive tasks). According to Gibson, Ivancevich, Donnelly, \& Konopaske [3], "workloads are pressures in response that cannot adapt, influenced by individual differences or psychological processes, namely a consequence of any external actions (environment, situations, too many events). make psychological or physical demands) on someone $"$.

Workload is a group or a number of activities that must be completed by an organization or position holder within a certain period. Workload is something that feels burdensome, goods or something carried, which is difficult to do as dependents.

Based on this opinion, it can be synthesized that workload is characterized as a number of activities, time, and energy that must be expended by someone both physically and mentally by giving their capacity to 
meet the demands of the given task. Every workload received by a person must be suitable and balanced both with physical abilities, cognitive abilities and the limitations of humans who accept these burdens.

\section{Work Stress (Stress)}

Expert Opinions of experts related to the definition of stress work is very beraga. According to Gibson et al., [3], "work stress is an adjustment response mediated by individual differences and / or psychological processes that are a consequence of any external (environmental) action, situation, or event that establishes excessive psychological and physical demands on a person".

Meanwhile, Eriyanto [4], explained that "work stress is a status that is experienced when a mismatch arises between the demands faced with the capabilities possessed". Then, Rivai [5] argues that "work stress is a condition of tension that creates a physical and psychological imbalance that affects the emotional thinking patterns and conditions of an employee".

According to Robbins [6], "work stress is a dynamic condition in which an individual is confronted with an opportunity, obstacle, or demand that is associated with what is very desirable and the results are perceived as uncertain and important". Meanwhile, according to Hasibuan [8], "stress is a condition of tension that affects one's emotions, thought processes, and conditions. People who experience stress become nervous and feel chronic worries. They often become angry, aggressive, unable to relax, or show uncooperative attitudes ".

Based on the description above, it can be synthesized that work stress is where a condition of an employee experiencing psychological or physical disorders in dealing with a problem or job. A condition where employees experience a mental or physical pressure that cannot keep up with the demands of the company. Job stress can be seen from symptoms such as unstable emotions, feeling uneasy, like to be alone, insomnia, anxiety, tension, nervousness, increased blood pressure, and experiencing indigestion.

\section{Work Motivation The}

Term motivation comes from the Latin word, namely: motive which means the cause, basic reason, basic thought of encouragement for someone to do or the main idea that always has a big influence on human behavior. Motive is sometimes interpreted as the needs, desires, impulses, gestures in a person. The motive is directed at the goal.

There are many theories about motivation. Among those stated by Maslow [8], as quoted by Indrawijaya [9], that achievement motives are reflected in their orientation towards goals and dedication for the best achievement of goals. The motive for affiliation is reflected in its desire to create, maintain, and develop relationships and an atmosphere of mysticism and mutual feelings of pleasure among human beings. Next in the motive for power a person feels encouraged when he can supervise and influence the actions of others.

According to Siswanto [10], motivation is (1) every feeling or will and desire that greatly influences the individual's will so that the individual is encouraged to behave and act; (2) the influence of forces that give rise to individual behavior; (3) every action or event that causes a change in someone's behavior; and (4) the process that determines the movement or behavior of individuals towards the goal.

Stevenson [11] considers that motivation is an incentive, impulse, or stimulus to action, or all verbal, physical, or psychological things that make a person do something in response. Based on the same thing also stated Walgito [12], that someone behaves must be related to the goals to be achieved, what drives it, and what is intended, in other words that human behavior always involves biological and psychological needs.

Robbins, Judge \& Sanghi [6], said that motivation as a process that produces an individual's intensity, direction, and perseverance in an effort to achieve a goal. The same thing was stated by Nawawi[13] that motivation is a condition that encourages or causes a person to do something or an activity carried out consciously, although it is also possible that under circumstances someone is forced to do something he does not like, so that power is driven by something that is not liked in the form of activities that are forced to do tend to take place effectively and efficiently.

Motivation can be divided into two forms namely intrinsic and extrinsic motivation. Intrinsic motivation is a driver of behavior that originates in a person as an individual, in the form of an awareness of the importance of the benefits / meaning of the work carried out, both because it is able to meet the needs or pleasing people that enables a person to be able to achieve a positive goal in the future. While extrinsic is a driver of work sourced from outside themselves as individuals in the form of a condition that requires workers to carry out their behavior optimally because of praise, punishment, rules, and so on.

Based on the above explanation, it can be synthesized that work motivation is an impulse that is in a person to do a job with indicators: 1) encouragement to work better, 2) pay attention to feedback, such as rewards to be received to what extent the individual have believed that performing at a certain level will encourage the achievement of output to be received 3) goal-oriented such as the impulse arising in a person to 
behave in achieving the goals set. 4) responsible, 5) dare to compete, 6) have a desire to enjoy success and 7) willingness to accept assignments.

\section{Productivity}

According to Sinungan [14], "productivity is an interdisciplinary approach to setting effective goals by using resources efficiently and still maintaining quality." While according to Mali, cited by Sedarmayanti [15], in his book entitled "Resources Human and Work Productivity "defines that," Productivity is how to produce or improve the results of goods and services as high as possible by utilizing resources efficiently. "According to Sutrisno [16]," productivity is a measure of productive efficiency or a comparison between outputs (goods or services) with inputs (labor, materials, money) ".

According to Kimsean [17], productivity is a measure of production efficiency, which is a comparison between output and input (output and input), input is often limited by labor input, while output is measured in physical units in the form of values.

Based on the description above, it can be synthesized that productivity is the ratio between the results that can be achieved (output) with the overall resources used, such as the results of increasing goods and services as high as possible by utilizing resources efficiently. The keys to achieving productivity such as responsible management expertise, extraordinary leadership, organizational and operational simplicity, effective staffing, challenging tasks, planning and controlling objectives, special managerial training by implementing these organizations can achieve effective and efficient productivity results.

\section{Conceptual Framework}

\section{Effect of Workload on Work Motivation}

Optimization at work must always be applied by all employees at work, but sometimes some employees feel excessive burden with the work they do so it affects their motivation at work. According Haryono et al., [18], excessive workload can cause a decrease in morale and motivation so that this becomes one of the causes of work fatigue. However, in reality if employees view all work that is charged is the responsibility of work, then the burden is not felt when employees complete their duties.

This is supported by previous research conducted by Dewi [19], that the perception of a positive workload is to assume that the workload is a work challenge and motivate them to work better for themselves and their organizations. Based on the above, basically the impact of the workload itself comes from the perceptions of each individual, sometimes there are individuals who are increasingly challenged with a large workload so that the motivation to complete a task is very large and such individuals do not feel excessive burden on their work will but on the contrary feel the passion, passion and passion in working.

\section{Effect of work stress on work motivation Work}

Stress is a condition that can cause tension that affects emotions, thoughts, and a person's physical condition. Rivai [5], states that "work stress is a condition of tension that creates a physical and psychological imbalance, which affects emotions, thought processes, the condition of an employee".

The level of stress that occurs in a company can cause a lack of employee motivation at work, as the main actors in an organization the human element needs to be maintained through various means. This is supported by Amela, Pratikto, \& Suharto's research [20] with the title The effect of role overload and work stress toward employee performance through work motivation (A study at PT. Surya Raya Lestari II in Central Mamuju Regency) shows that there is a significant influence and positive work stress on work motivation. Loghan [21] suggested that work stress is an undesirable reaction where he experiences a great stress or workload given to him. Thus, the work pressure of employees at PT. Surya Raya Lestari II in Central Mamuju Regency must be in accordance with work motivation so that employees can work well.

\section{Effect of workload on work productivity}

Permendagri No. 12/2008 states that workload is the amount of work that must be borne by an office / organizational unit and is the product of work volume and time norms. Workload is a group or a number of activities that must be completed by an organizational unit or position holder within a certain period of Menpan [1]. Munandar [22] defines "workloads are tasks assigned by workers or employees to be completed at a certain time by using the skills and potential of the workforce". Strengthened by Tazeem, Muhammad, Kashif ur Rehman, \& Ijaz ur Rehman [23] who stated that workload pressure can be positive leading to increased productivity.

\section{Effect of work stress on work productivity}

Stress problems, in essence, are often associated with understanding work stress that occurs in the work environment, namely in the process of interaction between an employee and his work, because the impact of stress at work can affect life, health, productivity, and income. The relationship of stress and productivity according to Rivai and Mulyadi [24] for companies the consequences arising from stress are increased absenteeism, decreased productivity, and can psychologically reduce organizational commitment, trigger feelings of alienation, and turnover ". 
Astria Semaksiani et al., Sch Bull, Oct 2019; 5(10): 560-571

This is supported by the results of research conducted by Tanjung \& Hutagalung [25] entitled The effect of work stress factors on employee work productivity at PT. Aido Mini Plaza Sibolga. Analysis of the data in this study used the ANOVA test which assumed that there was an influence of work stress factors. This is consistent with the opinion of Cooper \& Straw [26] assuming stress symptoms can affect work productivity, because factors that are the source of work stress include physical, behavioral, character, personality, emotional, intellectual, and interpersonal.
The effect of work motivation on work productivity

The result of Modeong \& Ogi's research [27] shows that the motivation variable in this study has a positive and significant effect on the work productivity variable at PT. Sumber Alfaria Trijaya Tbk. Manado branch. This study supports previous research Isyaha's[28] which shows motivation has a significant effect on work productivity.

Based on the explanation above about the flow of thought between research variables by referring to the results of previous research and expert opinion, it can be illustrated through the framework of the research model as follows:

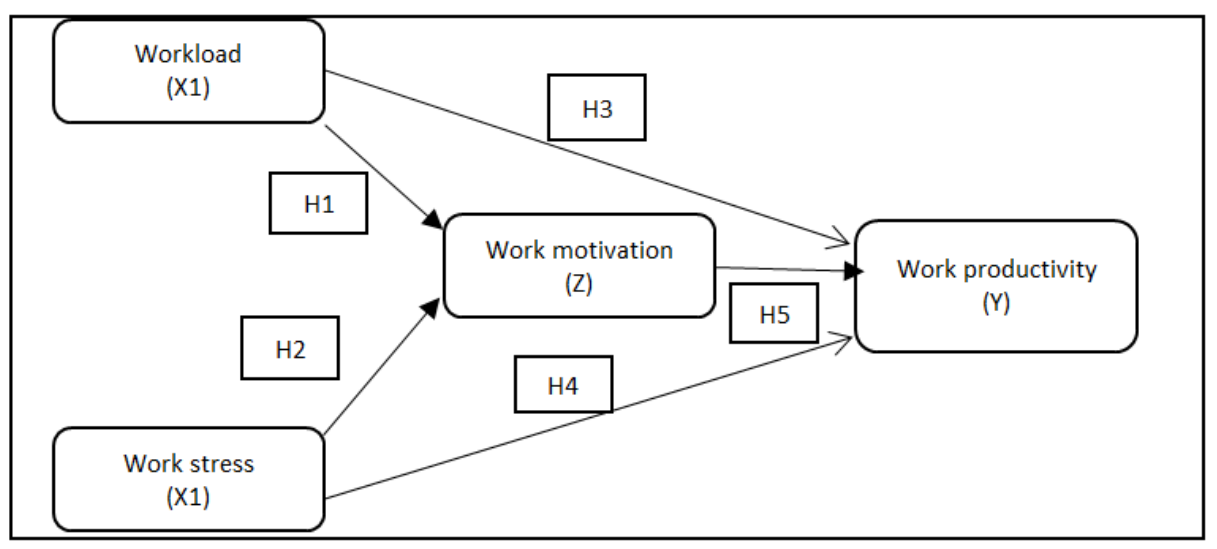

Fig-2: Concetual Framework

\section{Research Hypothesis}

1. H1: Workload has a positive and significant effect on employee work motivation at PT. Sumber Harapan Abadi

2. H2: Job stress has a positive and significant effect on employee work motivation at PT. Sumber Harapan Abadi

3. H3: Workload has a positive and significant effect on employee work productivity at PT. Sumber Harapan Abadi

4. H4: Job stress has a positive and significant effect on work productivity

5. H5: Work motivation has a positive and significant effect on work productivity

\section{RESEARCH METHODOLOGY}

This research is a quantitative study using survey methods. The intended survey research is to explain causal relationships or correlations which are commonly referred to as path analysis.

The affordable population of this research is all employees of PT. Sumber Harapan Abadi as many as 147 employees who are located on the street Garuda No. 12, Kemayoran, Central Jakarta. The sampling technique used is saturated sample, this technique was chosen based on the consideration that the researcher will use data analysis techniques using Lisrel which requires a lot of research samples. The data analysis technique used in this study is to use SEM (structural equation modeling). 


\section{RESULT AND DISCUSSION \\ Full model SEM}

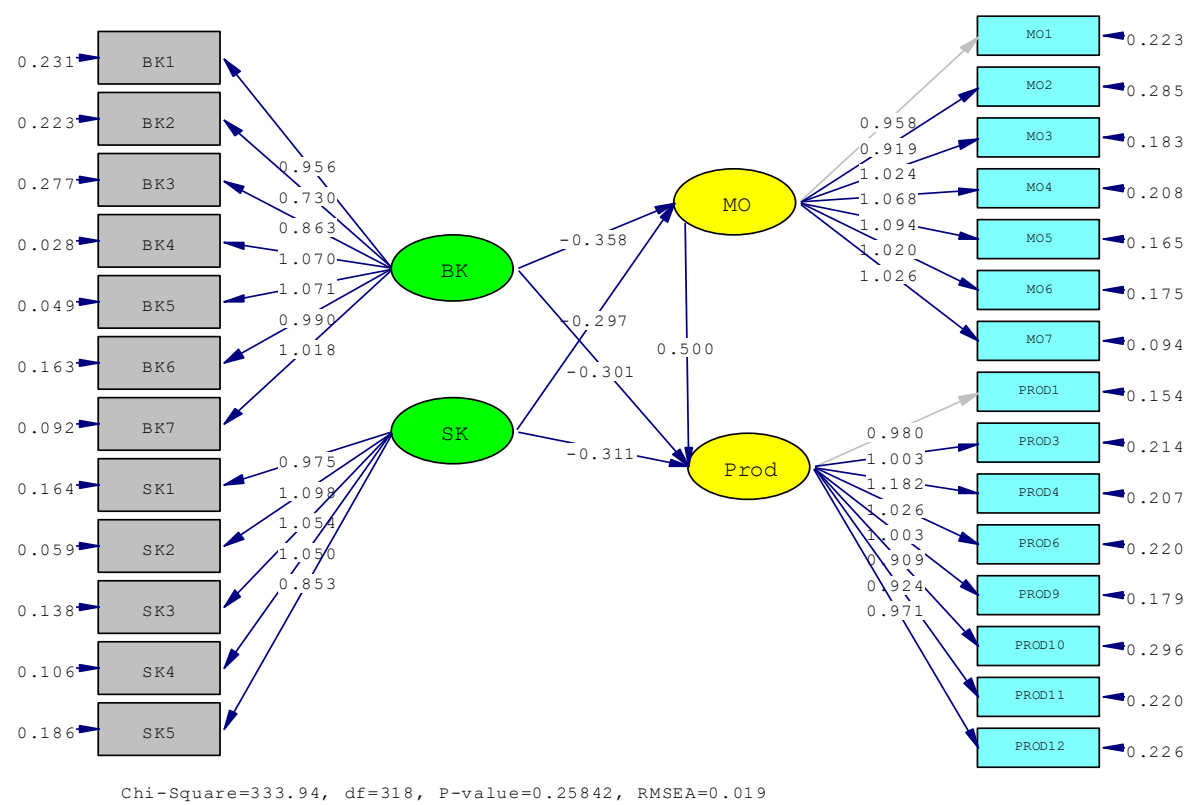

Fig-3: Full SEM model

Source: Data processed by researchers (2019)

Table-1: Full Model SEM

\begin{tabular}{|c|c|c|c|}
\hline Index & Cut Off Value & Results & Model Evaluation \\
\hline RMSEA & $\leq 0,08$ & 0,019 & Fitted \\
\hline GFI & $\geq 0,90$ & 0.855 & Margin Fitted \\
\hline CFI & $\geq 0,95$ & 0.997 & Fitted \\
\hline CMIN/DF & $\leq 2,00$ & 1.05 & Fitted \\
\hline RMR & $\leq 0,05$ & 0.0347 & Fitted \\
\hline AGFI & $\geq 0,90$ & 0.828 & Margin Fitted \\
\hline
\end{tabular}

Source: Processed by researchers (2019)

Based on the table goodness of fit above, it can be concluded that the model meets the index criteria goodness of fit. Therefore, modification of the model is not needed in order to find a fit model in accordance with the criteria for goodness of fit.

The Phase of first order construct the workload variable has 1 factor with 7 indicators. After processing the model in the SEM model fit analysis, no indicators must be eliminated.

The Stage of first order construct work stress variable has 1 factor with 5 indicators. After processing the model in a full SEM model analysis, no indicators must be eliminated.

The Phase of first order construct the motivational variable has 1 factor with 7 indicators. After processing the model in a full SEM model analysis, no indicators must be eliminated.
The Phase of first order construct the motivational variable has 1 factor with 12 indicators. After processing the model in full SEM model analysis, the first factor, there were 4 factors that were eliminated, namely PROD 2, PROD 5, PROD 7, and PROD 8.

Then the model fitness test (performed goodness of fit test) is by looking at the values in the predetermined criteria to find out whether the full SEM model is fit or not. RMSEA value is 0.019 , GFI is 0.855 , CFI is 0.997, CMIN / DF is 1.05, RMR is 0.0347 , and AGFI is 0.828. Based on these results the six measuring instruments ( $\mathrm{P}$, RMSEA, GFI, CFI, RMR, and AGFI) show good numbers in accordance with the index criteria, this indicates that the model is fit with existing data, there are 2 criteria that are margin fit. 
Table-2: Fit Model Indicator

\begin{tabular}{|c|c|}
\hline Item & Statement \\
\hline \multicolumn{2}{|r|}{ Workload } \\
\hline BK1 & My health is excellent to be able to complete the production target \\
\hline BK2 & I have good work motivation \\
\hline BK3 & I feel satisfied with the work I produce \\
\hline BK4 & I was given an assignment according to my ability \\
\hline BK5 & The target I have to achieve in work is too high \\
\hline BK6 & I feel confident and able to complete the targets set \\
\hline BK7 & Good machine condition helped me complete my production targets \\
\hline \multicolumn{2}{|r|}{ Job Stress } \\
\hline SK1 & Anxiety that arises due to work errors resulting in my heartbeat is irregular \\
\hline SK2 & I often get headaches if I can't bear the burden \\
\hline SK3 & My concentration was reduced because I was often tired \\
\hline SK4 & I often have difficulty falling asleep because of problems that occur at work \\
\hline SK5 & I cannot control my emotions when a conflict occurs \\
\hline \multicolumn{2}{|r|}{ Motivation } \\
\hline MO1 & I have the drive to work better \\
\hline $\mathrm{MO} 2$ & I pay attention to the feedback given by the company while working \\
\hline $\mathrm{MO} 3$ & I work to achieve the target set by the company \\
\hline MO 4 & I work responsibly \\
\hline MO5 & I am not interested in competing to achieve the targets set by the company \\
\hline MO6 & Work hard today to enjoy success in the future \\
\hline MO7 & I am willing to accept any assignment from the company \\
\hline \multicolumn{2}{|r|}{ Productivity } \\
\hline PRO1 & In carrying out my work I always try to achieve the targets set by the company \\
\hline PRO3 & I always try to finish work before the deadline determined by the company \\
\hline PRO4 & $\begin{array}{l}\text { I will continue to carry out the work immediately even if I am not required to be } \\
\text { resolved as soon as possible }\end{array}$ \\
\hline PRO6 & I will not switch to another restaurant set My work increases company profits \\
\hline PRO9 & Target work is not important, the important work is completed \\
\hline PRO10 & I always exceed the time limit in carrying out work \\
\hline PRO11 & I always try to improve the quality of work. \\
\hline PRO12 & I always try to improve my work \\
\hline
\end{tabular}

Source: Processed by researchers (2019)

\section{Direct and Indirect Effects}

Table-3: Direct and Indirect Effects

\begin{tabular}{|c|c|c|c|c|}
\hline Dependent variable & & independent Variable & Direct Influence & Indirect Influence \\
\hline Motivation & $\leftarrow$ & Workload & -0.358 & - \\
\hline Motivation & $\leftarrow$ & Work stress & -0.297 & - \\
\hline Productivity & $\leftarrow$ & Workload & -0.301 & 0.067 \\
\hline Productivity & $\leftarrow$ & Work stress & -0.311 & 0.067 \\
\hline Productivity & $\leftarrow$ & Motivation & 0.500 & - \\
\hline
\end{tabular}

Source: Data processed by researchers, 2019

Direct and indirect influence tests are carried out to find out whether there are direct or indirect effects of the independent variables that affect the dependent variable. Based on the results of data analysis, it can be seen that the direct effect of workload variables on motivation is -0.358 , the direct effect of work stress variables on motivation is -0.297 , the direct effect on workload variables on productivity is -0.301 , the indirect effect is 0.067 , the direct effect on work stress variables on productivity of -0.311 , indirect effect of 0.067 , and the direct effect of motivation variables on productivity of 0.500 . The indirect effect is only owned by the variable workload and work stress on productivity. This is because there is a mediating variable in the research model between workload and work stress on productivity, which is the motivation variable.

\section{Hypothesis Test}

If the $t$-value in the structural equation model results is greater than 1.96 , then there is a significant influence between the variables. Meanwhile, if the $t$ value is smaller than 1.96 , then the influence between variables is not significant 


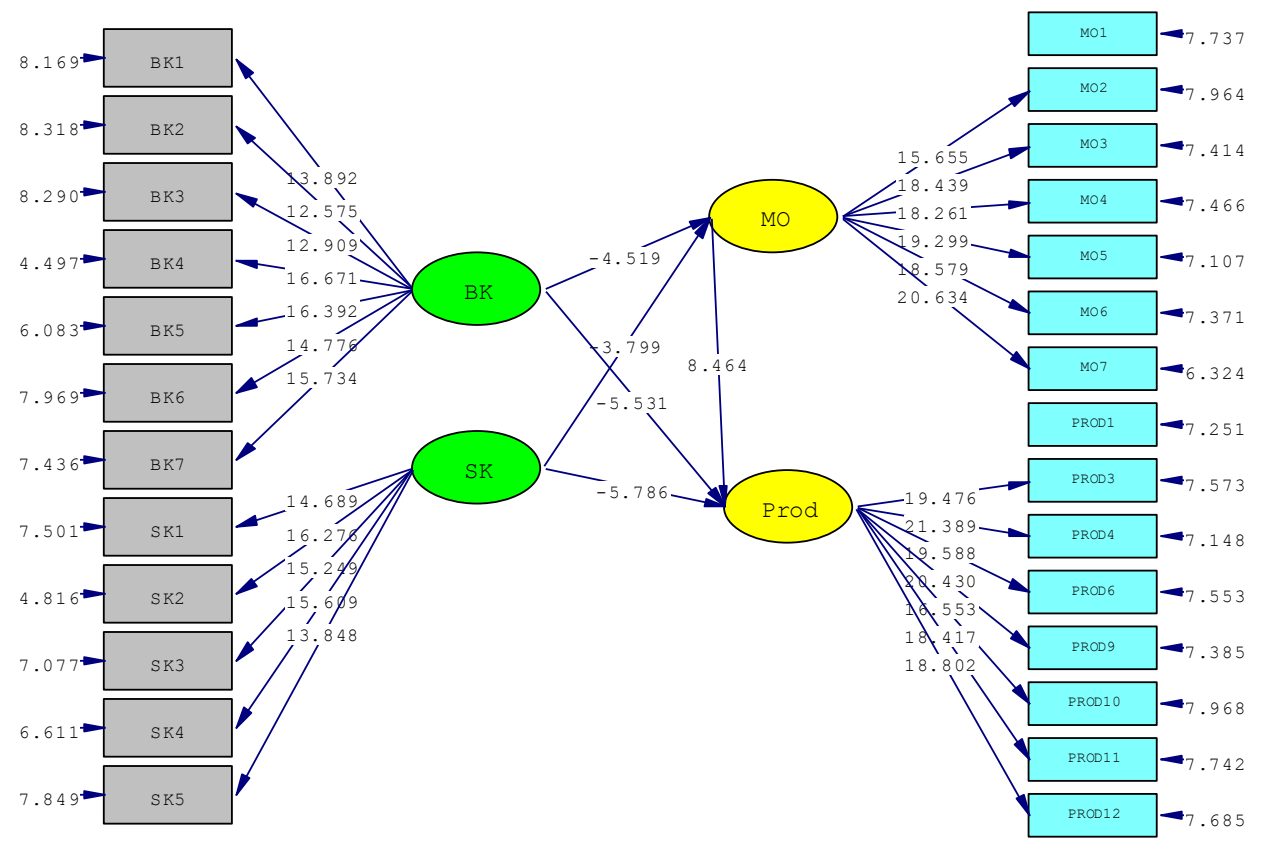

Fig-4: Hypothesis testing

Source: Data processed by researchers (2019)

Table-4: Structural Equation Model

\begin{tabular}{|c|c|c|c|c|c|c|}
\hline \multirow{3}{*}{ Hypothesis } & \multirow{3}{*}{$\begin{array}{l}\text { Dependent } \\
\text { variable }\end{array}$} & \multirow{3}{*}{\multicolumn{2}{|c|}{\begin{tabular}{c|c} 
Independent \\
Variable
\end{tabular}}} & \multirow{2}{*}{\multicolumn{3}{|c|}{$x^{2}$}} \\
\hline & & & & & & \\
\hline & & & & $\begin{array}{c}t- \\
\text { value }\end{array}$ & $\begin{array}{c}\text { Standardize total } \\
\text { effects }\end{array}$ & Interpretation \\
\hline H1a & Motivation & $\leftarrow$ & Workload & -4.519 & -0.358 & Be accepted \\
\hline $\mathrm{H} 1 \mathrm{~b}$ & Productivity & $\leftarrow$ & Workload & -5.531 & -0.301 & Be accepted \\
\hline $\mathrm{H} 2 \mathrm{a}$ & Motivation & $\leftarrow$ & Work stress & -3.799 & -0.297 & Be accepted \\
\hline $\mathrm{H} 2 \mathrm{~b}$ & Productivity & $\leftarrow$ & Work stress & -5.786 & -0.311 & Be accepted \\
\hline $\mathrm{H} 3$ & Productivity & $\leftarrow$ & Motivation & 8.464 & 0.500 & Be accepted \\
\hline
\end{tabular}

Source: data processed by researchers (2019)

Based on the results of the structural equation model above, all relationships between variables have a $t$-value greater than 1.96 or -1.96 . This means that there is a significant influence between variables. Hypothesis testing is done by looking at the value of standardized total effects in the structural equation model. Then the results of the hypothesis test can be seen as follows:

- variable on motivation on employees of PT Sumber Harapan Abadi Jakarta has a standardized total effects value Workloadof -0.358 , so the hypothesis that the workload on motivation has an effect of $35.8 \%$ and can be accepted.

- Variable workload on productivity of employees of PT Sumber Harapan Abadi Jakarta has a standardized total effects value of -0.301 , so hypothesis $1 \mathrm{~b}$ which states the workload on productivity has an effect of $30.1 \%$ and is acceptable.

- Variable work stress on motivation in employees of PT Sumber Harapan Abadi Jakarta has a standardized total effects value of -0.297 , so hypothesis $2 \mathrm{a}$ which states Work stress on motivation has an effect of $29.7 \%$ and is acceptable.

- Variable work stress on productivity of employees of PT Sumber Harapan Abadi Jakarta has a standardized total effects value of -0.311 , so hypothesis $2 b$ which states work stress on productivity has an effect of $31.1 \%$ and is acceptable. 


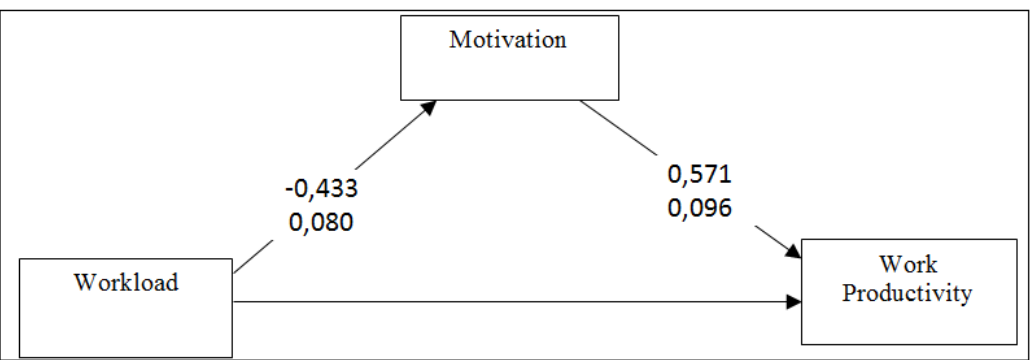

Fig-5: Sobel Test Effect of Workload on Productivity by Mediated Motivation

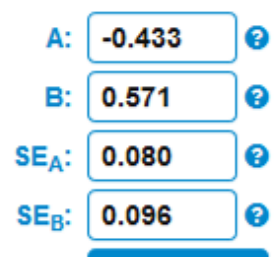

Calculate!

Sobel test statistic: -4.00314869

One-tailed probability: 0.00003125

Two-tailed probability: 0.00006250

Fig-6: Sobel Test

The results of the analysis with the sobel test showed a statistical value (z-value) for the influence of the motivation variable as an intervening variable between workload and productivity variables of 4.00314869 and significant on the Two-tailed probability with the number 0.00006250 . Because $\mathrm{z}$ value $>1.96$ or $p$-value $<\alpha=0.05$, it can be concluded that the indirect effect or indirect effect is significant, the mediation hypothesis is supported.

Effect of work stress on productivity with intervening variables Motivation

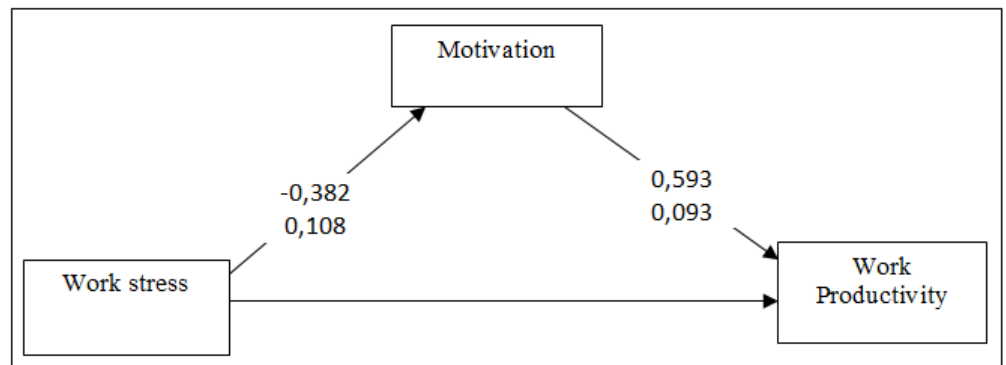

Fig-7: Effect of Work Stress on Productivity by Mediated Motivation

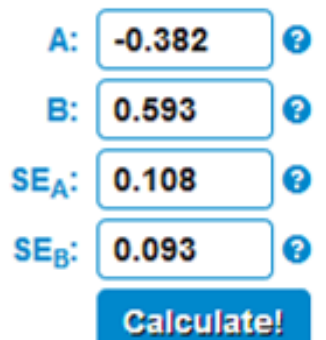

Sobel test statistic: $\mathbf{- 3 . 0 9 3 0 3 3 1 7}$

One-tailed probability: 0.00099061

Two-tailed probability: 0.00198122

Fig-8: Sobel Test 
The results of the analysis with the sobel test showed a statistical value (z-value) for the influence of the motivational variable as an intervening variable between the variables of work stress and productivity of -3.09303317 and significant on the Two-tailed probability with the number 0.00198122 . Because $\mathrm{z}$ value $>1.96$ or $p$-value $<\alpha=0.05$, it can be concluded that the indirect effect or indirect effect is significant. In line with previous findings using standardize total effects, the mediation hypothesis is supported.

\section{DISCUSSION}

Workload has a negative effect on motivation on employees of PT Sumber Harapan Abadi Jakarta

The results of this study prove that the workload on motivation on employees of PT Sumber Harapan Abadi Jakarta has a standardized total effects value of -0.358 , so the hypothesis stating workload on motivation has an effect of $35.8 \%$ and can be accepted.

The results of this study are in line with the opinion expressed by Haryono et al., [18], excessive workload can cause a decrease in morale and motivation so that this is one of the causes of work fatigue. However, in reality if employees view all work that is charged is the responsibility of working, then the burden is not felt when employees complete their duties. Based on the above, basically the impact of the workload itself comes from the perception of each individual, sometimes there are individuals which is increasingly challenged by a large workload so that the motivation to complete a task is very large and such individuals do not feel excessive burdens in their work but instead instead feel the enthusiasm, passion and excitement at work. While in research conducted by researchers, workload is considered as something that burdens employees that causes employees to decrease work motivation due to workload that exceeds their ability.

\section{Workload negatively affects the productivity of PT Sumber Harapan Abadi Jakarta employees. The}

Results of this study prove that the workload on productivity of PT Sumber Harapan Abadi Jakarta employees has a standardized total effects value of 0.301 , so the hypothesis stating workload on motivation has an effect of $30.1 \%$ and can be accepted.

This finding supports the results of previous research by Saefullah [28], which states that there is an influence between the workload variable on the work productivity of production employees of PT. Venia Agape Indonesia. different from the opinions expressed by Shah, et al. [29] states workload pressure can be positive leading to increased productivity. Just as with the effect on motivation, the effect on productivity also depends on the employee looking at the workload. Employees who view workload as a challenge will make work productivity increase.
Work stress has a negative effect on motivation in employees of PT Sumber Harapan Abadi Jakarta

The results of this study prove that there is a significant negative effect of work stress on motivation in employees of PT Sumber Harapan Abadi Jakarta, which has a standardized total effects value of -0.297 , so hypothesis $2 \mathrm{a}$ which states work stress towards motivation has an effect of $29.7 \%$ and is acceptable.

The results of this study are in line with the concept put forward by Rivai [5] suggesting that, "work stress is a condition of tension that creates a physical and psychological imbalance, which affects emotions, thought processes, the condition of an employee". Istijanto argues that, "stress arises when employees are unable to meet the demands of the job. Lack of clarity about what is the responsibility of the job, lack of time to complete the task, there is no support facilities to carry out the work, work tasks that conflict with each other, are triggers of stress ".

Job Stress has a negative effect on Work Productivity the employees of PT Sumber Harapan Abadi Jakarta

The results of this study prove that there is a significant negative effect of work stress on the work productivity of employees of PT Sumber Harapan Abadi Jakarta has a standardized total effects value of 0.311 , so hypothesis $2 b$ which states work stress on productivity has an effect of $31.1 \%$ and acceptable.

The relationship of stress and productivity according to Rivai and Mulyadi [5] for companies the consequences arising from stress are increased absenteeism, decreased productivity, and can psychologically reduce organizational commitment, trigger feelings of alienation, and turnover ".

This is supported by the results of research conducted by Tanjung \& Hutagalung [24] entitled The effect of work stress factors on employee work productivity at PT. Aido Mini Plaza Sibolga. Analysis of the data in this study used the ANOVA test which assumed that there was an influence of work stress factors. This is in accordance with the opinion of Cooper \& Straw [25] assuming stress symptoms can affect work productivity, because factors that are the source of work stress include physical, behavioral, character, personality, emotional, intellectual, and interpersonal.

Motivation has a positive effect on productivity on employees of PT Sumber Harapan Abadi Jakarta

The results of this study prove that there is a significant positive influence on motivation on productivity of employees at PT Sumber Harapan Abadi Jakarta has a standardized total effects value of 0.500 , so hypothesis 3 which states motivation on 
Astria Semaksiani et al., Sch Bull, Oct 2019; 5(10): 560-571

productivity has an effect of $50.0 \%$ and can be accepted.

The results of this study are in line with Modeong \& Ogi [26] showing that the motivation variable in this study has a positive and significant effect on the variable work productivity at PT. Sumber Alfaria Trijaya Tbk. Manado branch. This study supports Isyana's previous research [27] which shows motivation has a significant effect on work productivity.

This research discusses about Work Motivation and Work Productivity. This research is in line with previous studies including: Riyanto [30], Pajian [31] and Prayetno [32].

\section{CONCLUSION AND SUGGESTION CONCLUSION}

The results of this study reinforce the theory that:

- The description of Workload felt by the examiner is classified as heavy as evidenced by the hypothesis $\mathrm{H} 1$ statement is accepted.

- Workload variable has a negative and significant effect on employee productivity and has a Standardize total effects of -0.301 .

- Work stress variable has a negative and significant effect on employee motivation and has a standardize total effects of -0.297 .

- Stress variable has a negative and significant effect on employee productivity and has a standardize total effects of -0.311 .

- Motivational variables have a positive and significant effect on employee work productivity and have a standardize total effects of 0.500 , so that hypothesis 5 has a positive effect of $50.0 \%$

\section{SUGGESTION}

- To get a comparison and strengthen the theory of influence among the variables studied, it is necessary to conduct a study or review using different research objects or in the same industry with different locations as in other areas in Jakarta.

- $\quad$ Future studies can use a wider and wider number of samples, and add references and more recent research reviews so that research results are accurate.

- In future studies, research variables can be added such as job satisfaction, career development, compensation that can be investigated as well as whether these variables can affect motivation and productivity.

\section{REFERENCES}

1. Kepmenpan No: KEP / 75 / M.PAN / 7/2004: https://www.menpan.go.id

2. Prihatini, L. D. (2007). Analysis of the relationship of workload with nurses work stress in each inpatient room at Sidikalang Regional Hospital. University of North Sumatra, Medan.

3. Gibson, J. L., Ivancevich, J. M., Donnelly, J. H., \& Konopaske, R. (2012). Organizations: Behavior, Structure, Processes (14th ed.). New York: McGraw-Hill Company, Inc.

4. Eriyanto. (2011). Content analysis: Introduction to the methodology for communication research and other social sciences. Jakarta: Kencana Prenada Media Group

5. Rivai, V. (2004). Human resource management for companies: From theory to practice. Jakarta: PT. Raja Grafindo Persada

6. Robbins, S. P., Judge, T. A., \& Sanghi, S. (2009). Organizational behavior. New Delhi: Dorling Kindersley pvt. Ltd.

7. Hasibuan, M. S. P. (2007). Human resource management (Revised). Jakarta: Earth Literacy.

8. Maslow, A. (1965). Eupsychian Management: A Journal. Publisher RD Irwin.

9. Indrawijaya. (2003). Organizational behavior. Jakarta: Sinar Baru.

10. Siswanto, H. B. (2009). Introduction to management (5th ed.). Jakarta: Earth Literacy.

11. Stevenson, W. J. (2010). Production / operation management (3rd ed.). Tokyo, Japan:, Richard D Irwin Inc. and Toppan Company Ltd.

12. Walgito, B. (2010). Introduction to general psychology (Revised). Yogyakarta: CV. Andi Offset.

13. Nawawi, H. (2009). Human resource management for competitive businesses. Jakarta: Earth Literacy.

14. Sinungan, M. (2009). Productivity: What and how. Jakarta: Earth Literacy.

15. Awarmayanti. (2001). Become a better manager. Jakarta: Binarupa Aksara.

16. Sutrisno, E. (2010). Human Resource Management. Jakarta: Kencana Prenada Media Group.

17. Kimsean, Y. (2011). Employee work productivity in bureaucracy. In AT Sulistiyani (Ed.), Understanding Good Governance in the Perspective of Human Resources. Yogyakarta: Gava Media.

18. 18 Hariyono, W., Suryani, D., \& Wulandari, Y. (2009). The relationship between workload, work stress and the level of conflict with nurse work fatigue at the Yogyakarta Islamic Hospital PDHI Yogyakarta City. Journal of Public Health UAD, 3(3), 186-197.

19. Dewi, U., \& Satrya, A. (2012). Analysis of workforce needs based on employee workload at PT PLN (Persero) Jakarta Raya and Tangerang Distribution in the field of human resources and organizations. Jakarta: University of Indonesia.

20. Amela, S. L., \& Heri, P. S. (2018). The Effect of Role Overload and Job Stress on Employee Performance through Work Motivation (Study at PT Surya Raya Lestari II in Central Mamuju 
Regency), Thesis, Management Study Program, Postgraduate, Malang State University

21. Logan, A., Ali, A. A., \& Adan, A. A. (2013). Working conditions and employees' productivity in manufacturing companies in Sub-Saharan African Context: Case of Somalia. Educational Research International, 2(2), 67-78.

22. Munandar. (2001). Industrial and organizational psychology. Jakarta: UI Press.

23. Ali, A., Ali, A. A., \& Adan, A. A. (2013). Working conditions and employees' productivity in manufacturing companies in Sub-Saharan African Context: Case of Somalia. Educational Research International, 2(2), 67-78.

24. Tanjung, M., \& Hutagalung, H. (2018). The Effect of Work Stress Factors on Employee Productivity at PT. Aido Mini Plaza Sibolga. Jesya (Journal of Sharia Economics \& Economics), 1(1), 77-86. Retrieved from https://stiealwashliyahsibolga.ac.id/jurnal/index.ph p/jesya/article/view/8

25. Cary, C., \& Alison, S. (2009). Successful Stress Management for the Week. Jakarta: Kesaint Blanc

26. Modeong O. E., \& Imelda, W. J. (2019). The Effect Of Work Stress And Work Loads On Employee Performance In PT. Bank Tabungan Negara (Persero) TBK, Branch Manado. EMBA Journal, $5(2)$. https://ejournal.unsrat.ac.id/index.php/emba/article / view / 16500/15992

27. Sunarso. (2010). The influence of leadership, discipline, workload and work motivation on school teacher performance. Journal of Human Resource Management, 4(1).

28. Syed, A. A. S. G., Anka, L. M., Jamali, M. B., \& Shaikh, F. M. (2012). Motivation as a tool for effective staff productivity in the public sector: A case study of raw materials research and development council of Nigeria.Asian Social Science, 8(11), 85.

29. Saefullah, E., \& Amalia, A. N. (2017). Pengaruh Beban Kerja dan Stres Kerja Terhadap Produktivitas Kerja Karyawan. Jurnal Akademika, 15(2), 117-121.

30. Riyanto, S., Sutrisno, A., \& Ali, H. (2017). The Impact of Working Motivation and Working Environment on Employees Performance in Indonesia Stock Exchange. International Review of Management and Marketing, 7(3), 342-348. Retrieved from http://dergipark.org.tr/irmm/issue/32110/356036.

31. Paijan, P., \& Ali, H. (2017). The Influence of Transformational Leadership Style, Training on Work Motivation and the Implications of the Performance of Education Personnel at Mercu Buana University, Jakarta. Journal of Economics, 21(3).

32. Prayetno, S., \& Ali, H. (2017). Analysis of Advocates Organizational Commitment and Advocates Work Motivation to Advocates Performance And its Impact on Performance Advocates Office. International Journal of Economic Research. 